\title{
Pengaruh Panjang Penyaluran Tambahan Pada Balok Beton Bertulang
}

\author{
Elfania Bastian \\ Fakultas Teknik, Univeristas Muhammadiyah Sumatera Barat \\ Jl. Pasir Kandang No.4 Koto Tangah Padang \\ email: elfania_bastian@ymail.com
}

\begin{abstract}
Pada konstruksi bangunan khususnya gedung, beton bertulang merupakan salah satu pilihan terbaik. Hal ini disebabkan oleh kemampuan beton dalam menahan tekan dikombinasikan dengan baja yang memiliki kemampuan menahan tarik. Salah satu elemen struktur yang biasanya menggunakan beton bertulang adalah balok. Kemampuan balok menahan beban dipegaruhi oleh interaksi antara tulangan baja dengan beton yang berada disekelilingnya yang disebut lekatan (bond). Selain lekatan, kinerja beton bertulang juga dipengaruhi oleh panjang penyaluran tambahan. Analisis pengaruh lekatan dan panjang penyaluran tambahan pada balok beton bertulang dilakukan dengan menggunakan model numeric dengan jenis tulangan yang berbeda. Dimana panjang penyaluran tambahan divariasikan $100 \mathrm{~mm}$ dan $250 \mathrm{~mm}$. Tulangan yang digunakan adalah tulangan baja. Hasil analisis menjelaskan bahwa penambahan penyaluran tambahan mampu meningkatkan kapasitas balok pada beton dengan lekatan sempurna ataupun dengan menggunakan bond model.
\end{abstract}

Keywords: Balok, Beton Bertulang, Kapasitas Balok

\section{PENDAHULUAN}

Beton bertulang merupakan gabungan dari beton dan tulangan baja. Beton merupakan bahan yang memiliki kekuatan tekan yang tinggi akan tetapi memiliki kekuatan tarik yang rendah. Sedangkan tulangan baja akan memberi kekuatan tarik yang besar. Pada penerapannya dilapangan diharapkan dengan adanya kelebihan masing-masing elemen tersebut, maka penggunaan beton bertulang menjadi sangat efisien untuk memikul beban pada struktur, sesuai dengan kapasitas dan umur layan yang ditetapkan.

Beton bertulang memiliki kelebihan diantaranya yaitu (Jack. C, 2004) :

1. Beton memiliki kuat tekan yang relatif lebih tinggi debanding dengan kebanyakan bahan lain.

2. Beton bertulang mempunyai ketahanan yang tinggi terhadap api dan air.

3. Struktur beton bertulang sangat kokoh

4. Beton bertulang tidak memerlukan biaya pemeliharaan yang tinggi.

5. Dibandingkan dengan bahan lain, beton bertulang memiliki usia layan yang sangat panjang.

6. Merupakan bahan yang ekonomis.
7. Beton bertulang bisa di cetak menjadi berbagai bentuk yang beragam.

8. Bahan-bahan pembuatan beton bertulang mudak diperoleh.

9. Pengerjaan tidak hanya bisa dilakukan oleh tim ahli.

Kinerja atau kemampuan balok beton bertulang dalam menahan beban dipengaruhi oleh beberapa hal. Diataranya, panjang penyaluran tambahan. Panjang penyaluran tambahan adalah panjang/ jarak antara tumpuan dan pinggir balok. Selain itu dipengaruhi juga oleh lekatan (bond) yang merupakan interaksi antara tulangan baja dengan beton yang berada disekelilingnya, yang akan mencegah terjadinya slip dari baja relatif terhadap beton. Sehingga masingmasing elemen dapat berfungsi dengan baik. Selain itu

Kajian mengenai lekatan antara baja dan beton terus berkembang. Salah satunya permodelan yang dilakukan oleh J.Larralde (1992). Kajian ini perlu dilakukan mengingat pada pengerjaan konstruksi lekatan baja dan beton sulit untuk mencapai kondisi lekat sempurna (Perfect bond). Pada penelitian ini di analisa pengaruh panjang penyaluran tambahan $100 \mathrm{~mm}$ dan $250 \mathrm{~mm}$. Dengan 
memvariasikan lekatan baja dan beton menggunakan metode numerik.

\section{METODE PENELITIAN}

Analisis numerik dilakukan dengan bantuan perangkat lunak komputer berbasis metode elemen hingga ATENA (Cervenka, 2011). Analisis dilakukan pada balok beton bertulang dengan penampang dan ukuran seperti yang terlihat pada gambar 1 .
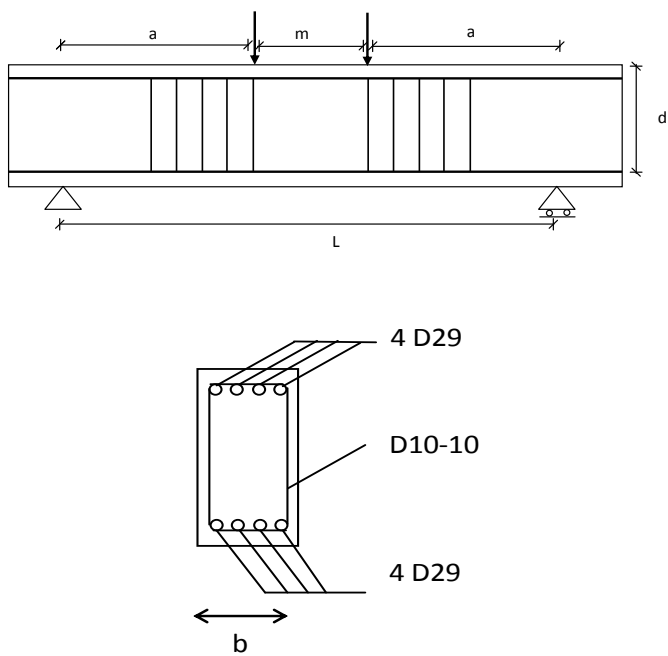

Gambar 1. Balok beton bertulang untuk pengujian

Tabel 1. Propertis Balok

\begin{tabular}{l|c|l|l}
\multicolumn{1}{c|}{ Uraian } & Notasi & Satuan & Besar \\
\hline Panjang Balok & $\mathrm{L}$ & $\mathrm{mm}$ & 2500 \\
Lebar Balok & $\mathrm{b}$ & $\mathrm{mm}$ & 250 \\
Tinggi Balok & $\mathrm{h}$ & $\mathrm{mm}$ & 500 \\
Tinggi efektif & $\mathrm{d}$ & $\mathrm{mm}$ & 455.5 \\
Panjang & $\mathrm{a}$ & $\mathrm{mm}$ & 1000 \\
Bentang Geser & $\mathrm{m}$ & $\mathrm{mm}$ & 500 \\
Jarak Antar & & & \\
Beban & & & \\
\hline
\end{tabular}

\section{Material}

Beton pada permodelan elemen hingga menggunakan material SBETA karena pada material ini sifatnya diasumsikan sama dengan sifat beton pada umumnya. Pada permodelan ini kuat tekan beton diasumsi kan sebesar $30 \mathrm{MPa}$. Sedangkan modulus elastisitas, poisson's ratio dan tensile strength dihitung oleh perangkat lunak Atena. Untuk lebih jelasnya material propertisnya beton bisa dilihat pada Tabel.2
Tabel 2. Propertis material beton

\begin{tabular}{c|c|cc} 
Propertis & Notasi & Satuan & Besar \\
\hline Elastic Modulus & $\mathrm{Ec}$ & $\mathrm{MPa}$ & $3.03 \mathrm{E}+04$ \\
\hline Poisson' is Ratio & $\mu$ & - & 0.02 \\
Tensile Streng th & $\mathrm{Ft}$ & $\mathrm{MPa}$ & 2.582 \\
\hline Compressive Strength & $\mathrm{Fc}$ & $\mathrm{MPa}$ & 30
\end{tabular}

Tabel 3. Propertis material tulangan baja

$$
\begin{aligned}
& \quad \text { Propertis } \\
& \text { Modulus Elastisitas } \\
& \text { Regangan } \\
& \text { Tegangan Yield } \\
& \text { Tegangan Ultimate }
\end{aligned}
$$

\begin{tabular}{ll} 
Notasi & \multicolumn{1}{c}{ Satuan } \\
$\mathrm{B}$ & $\mathrm{MPa}$ \\
$\sigma_{\mathrm{m}}$ & - \\
$\sigma_{y}$ & $\mathrm{MPa}$ \\
$\sigma$, & $\mathrm{MPa}$
\end{tabular}

\section{Permodelan Bond Model (Model Linier Local Bond Stress-Slip)}

Permodelan lekatan antara tulangan dan beton diasumsikan berperilaku linier. Dengan mengacu kepada hasil pengujian J.Larralde (1992), model linier dapat ditentukan seperti yang diperlihatkan dalam Gambar 2.

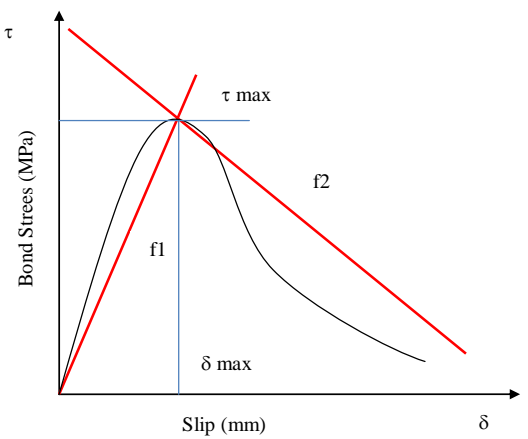

Gambar 2. Permodelan Linier Local Bond Stress-Slip

\section{Variasi Model Numerik}

Balok beton bertulang pada permodelan ini divariasikan bersarkan jenis lekatan yaitu perfect bond dan bond model. Yang di variasikan dengan perbedaan panjang penyaluran tambahan. Seperti pada tabel 4 .

Tabel 4. Variasi model numeric

\begin{tabular}{c|l|l|l}
\hline \multicolumn{1}{c|}{ Uraian } & $\begin{array}{c}\text { Jenis } \\
\text { Tulangan }\end{array}$ & $\begin{array}{c}\text { Panjang Penyaluran } \\
\text { Tambahan }\end{array}$ & $\begin{array}{c}\text { Kode } \\
\text { Model }\end{array}$ \\
\hline Perfect Bond & Baja & $100 \mathrm{~mm}$ & BS-1 \\
Perfect Bond & Baja & $250 \mathrm{~mm}$ & BS-2 \\
Bond Model & Baja & $100 \mathrm{~mm}$ & BSB-1 \\
Bond Model & Baja & $250 \mathrm{~mm}$ & BSB-2
\end{tabular}




\section{HASIL DAN PEMBAHASAN}

Setelah dilakukan analisis secara numerik. Balok beton bertulang dengan variasi panjang penyaluran tambahan 100 $\mathrm{mm}$ dan $250 \mathrm{~mm}$ diperoleh hasil yang digambarkan dlam kurva beban vs deformasi. Untuk hasil yang lebih baik maka analisa dilakukan menggunakan dua jenis lekatan. Yaitu dengan prinsip lekatan sempurna dan menggunakan bond model.

Hasil analisa menujukkan bahwa panjang penyaluran tambahan memiliki konstribusi dalam meningkatkan kemampuan balok dalam menahan beban. Seperti terlihat pada gambar 3. Balok dengan panjang penyaluran $100 \mathrm{~mm}$ memiliki kapasitas maksimum sebesar 360,3 kN. Dengan adanya penambahan panjang penyaluran tambahan menjadi $250 \mathrm{~mm}$ maka kapasitas balok beton bertulang meningkat menjadi 433,4 kN sebesar 16,86\%. Selain itu pada gambar 3 dapat dilihat saat panjang penyaluran $250 \mathrm{~mm}$ deformasi mencapai 7,23 $\mathrm{cm}$ sedangkan dengan panjang penyaluran tambahan $100 \mathrm{~mm}$ deformasi saat beban maksimum 6,27 mm.

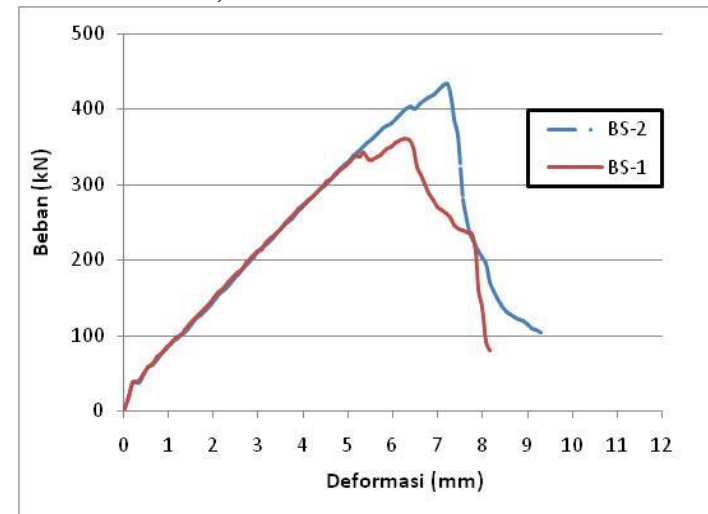

Gambar 3. Beban vs Deformasi Panjang Penyaluran Tambahan $250 \mathrm{~mm}$

Analisis dengan menggunakan Bond Model, permodelannya dibuat dengan menggunakan model linier. Digunakan data eksperimental J.Larralde 1992 yang dimodelkan dalam bentuk linier. Penggunaan model bond dimaksudkan agar memperkuat hasil analisa mengenai pengaruh panjang penyaluran tambahan. Saat digunakan bond model, hasil menunjukkan bahwa dengan menambah panjang penyaluran tambahan, kapasitas balok dapat meningkat sebesar 26,67\%. Yang digambarkan dalam gambar 4

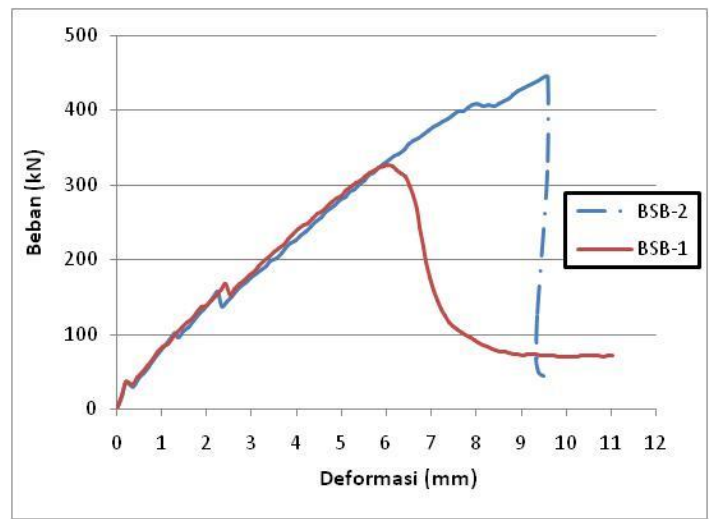

Gambar 4. Beban vs Deformasi Panjang Penyaluran Tambahan $100 \mathrm{~mm}$

\section{SIMPULAN}

Berdasarkan hasil dari analisa penyaluran tambahan memiliki pengaruh terhadap kapasitas balok dalam menahan beban. 16,86\% untuk permodelan lekatan sempurna dan $26,67 \%$ dengan menggunakan bond model.

\section{UCAPAN TERIMAKASIH}

Alhamdulillah dengan rahmat Allah penulis dapat menyelesaikan penelitian ini. Terimakasih untuk keluarga, dan FT.UMSB atas dukungan dan doa.

\section{DAFTAR PUSTAKA}

Baja Tulangan Beton (SII 0136-84)

Cervenka, V. Jendele, L. and Cervenka, J.

"ATENA Program Documentation

Part 1, Theory" Prague, February 23. 2011.

Jack,C .Cormac, MC. "Desain Beton Bertulang”. Erlangga, Jakarta. 2004.

Jensen, A, Chenoweth,H. "Kekuatan Bahan Terapan”. Erlangga, Jakarta. 1991

Larralde,J.and Rodriguez. Silva. "Bond and Slip of FRP Rebars in Concrete". Journal of Materials in Civil Engineering, Vol. 5, No.1. February, 1993

Morita, S. and Fujii, S. (1982), "Bond Capacity of Deformed Bars Due to Splitting of Surrounding Concrete", Bond in Concrete, edited by Bartos. 
P., Applied Science Publisher, pp. 331-341.

Paulay, T and R.Park. "Reinforced Concrete Structure". John Wiley \&Sons. Inc. United States of America. 1975 